\title{
Dimethyl sulfoxide solvates of the aluminium(III), gallium(III) and indium(III) ions. A crystallographic, EXAFS and vibrational spectroscopic study $\dagger$
}

\author{
Alireza Molla-Abbassi, ${ }^{a}$ Mikhail Skripkin, ${ }^{b}$ Mikael Kritikos, ${ }^{a}$ Ingmar Persson, ${ }^{c}$ János Mink ${ }^{d, c}$ \\ and Magnus Sandström*a \\ ${ }^{a}$ Department of Structural Chemistry, Arrhenius Laboratory, University of Stockholm, \\ SE-106 91 Stockholm, Sweden \\ ${ }^{b}$ St. Petersburg State University, Department of Chemistry, Universitetskii pr. 26, 198504, \\ St. Petersburg, Russia \\ ${ }^{c}$ Department of Chemistry, Swedish University of Agricultural Sciences, P. O. Box 7015, \\ SE-750 07 Uppsala, Sweden \\ ${ }^{d}$ Institute of Isotopes and Surface Chemistry, Chemical Research Center of the Hungarian \\ Academy of Sciences, P.O. Box 77, H-1525, Budapest, Hungary \\ e Analytical Chemistry Department and Research Group of HAS, University of Veszprém, \\ P.O. Box 158, H-8201, Veszprém, Hungary
}

Received 6th December 2002, Accepted 13th March 2003

First published as an Advance Article on the web 26th March 2003

\begin{abstract}
The isostructural hexakis(dimethyl sulfoxide)-aluminium(III), -gallium(III) and -indium(III) iodides crystallise in the trigonal space group $R \overline{3}$ (no. 148), $Z=3$, at $295 \pm 1 \mathrm{~K}$. The metal ions are located in a $\overline{3}$ symmetry site with $\mathrm{M}-\mathrm{O}$

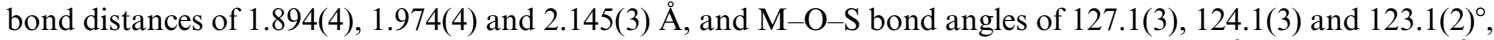
for $\mathrm{M}=\mathrm{Al}, \mathrm{Ga}$ and In, respectively. The unit cell parameters are $a=10.762(2), c=24.599(3) \AA, V=2467.2(5) \AA^{3}$ for $\left[\mathrm{Al}\left(\mathrm{OS}\left(\mathrm{CH}_{3}\right)_{2}\right)_{6}\right] \mathrm{I}_{3}, a=10.927(2), c=23.868(4) \AA, V=2468.1(6) \AA^{3}$ for $\left[\mathrm{Ga}\left(\mathrm{OS}\left(\mathrm{CH}_{3}\right)_{2}\right)_{6}\right] \mathrm{I}_{3}$, and $a=11.358(2)$, $c=21.512(4) \AA, V=2403.5(7) \AA^{3}$ for $\left[\operatorname{In}\left(\mathrm{OS}\left(\mathrm{CH}_{3}\right)_{2}\right)_{6}\right] \mathrm{I}_{3}$. The increasing compression of the octahedral $\mathrm{MO}_{6}$ coordination entities along one three-fold axis for $\mathrm{M}=\mathrm{Al}, \mathrm{Ga}$ and In, respectively, explains why the largest ion indium(III) has the smallest unit cell volume. EXAFS measurements on the dimethyl sulfoxide solvated gallium(III) and indium(III) ions in solution and in the solid perchlorate and trifluoromethanesulfonate salts, show similar bond distances as in the solid iodide solvates. Raman and infrared spectra have been recorded for the hexakis(dimethyl sulfoxide)metal(III) iodides and the nature of the metal-sulfoxide bond has been evaluated by normal coordinate methods. The symmetric and asymmetric M-O stretching modes correspond to the vibrational frequencies 465 and $540 \mathrm{~cm}^{-1}$ for $\left[\mathrm{Al}\left(\mathrm{OS}\left(\mathrm{CH}_{3}\right)_{2}\right)_{6}\right] \mathrm{I}_{3}, 491$ and $495 \mathrm{~cm}^{-1}$ for $\left[\mathrm{Ga}\left(\mathrm{OS}\left(\mathrm{CH}_{3}\right)_{2}\right)_{6}\right] \mathrm{I}_{3}$, and 444 and $440 \mathrm{~cm}^{-1}$ for $\left[\operatorname{In}\left(\mathrm{OS}\left(\mathrm{CH}_{3}\right)_{2}\right)_{6}\right] \mathrm{I}_{3}$, respectively.
\end{abstract}

\section{Introduction}

The oxygen coordination of the aluminium(III), gallium(III) and indium(III) ions is well characterised in crystal structures. The mean $\mathrm{Al}-\mathrm{O}$ bond distance for hexaaquaaluminium(III) complexes in the solid state is $c a .1 .88 \AA \AA^{1,2}$ Tetrahedral aluminium complexes with oxygen donor ligands, as e.g. sodium tectohexaoxoalumodisilicate hydrate, $\mathrm{Na}\left(\mathrm{AlSi}_{2} \mathrm{O}_{6}\right) \cdot \mathrm{H}_{2} \mathrm{O},{ }^{3}$ display much shorter $\mathrm{Al}-\mathrm{O}$ bond distances, about $1.65 \AA$. Oxygencoordinated gallium(III) complexes are normally octahedral with mean $\mathrm{Ga}-\mathrm{O}$ bond distances close to $1.97 \AA \AA^{1,2} \mathrm{~A}$ fourcoordinated gallium(III) complex with tetrahedral oxygen environment, $\mathrm{LiGaO}_{2} \cdot 6 \mathrm{H}_{2} \mathrm{O}$, showed a significantly shorter $\mathrm{Ga}-\mathrm{O}$ bond distance, $1.826(5) \AA{ }^{4}{ }^{4}$ Octahedral indium(III) complexes display mean In-O bond distances close to $2.13 \AA$. $^{1,2}$

The coordination number of the hydrated trivalent metal ions in group 13, aluminium(III), ${ }^{5}$ gallium(III) ${ }^{6}$ indium(III) ${ }^{6}$ and thallium(III), ${ }^{7}$ is six, while the hydration number in aqueous solution of the trivalent metal ions in group 3 increases with increasing atomic number. Scandium(III) probably coordinates

$\uparrow$ Electronic supplementary information (ESI) available: normalized Xray absorption edges, calculated separate contributions of the different scattering paths to the EXAFS oscillations for the dimethyl sulfoxide solvated gallium(III) and indium(III) ions in the solid state and solution; correlation between compression ratio $(s / h)$ and bond lengths in $\left[\mathrm{M}(\mathrm{dmso})_{6}\right]^{3+}$ complexes; correlation between metal-oxygen $(\mathrm{M}-\mathrm{O})$ force constants and bond lengths in $\left[\mathrm{M}(\mathrm{dmso})_{6}\right]^{3+}$ complexes. See http:// www.rsc.org/suppdata/dt/b2/b212140a/ seven water molecules in a monocapped trigonal prism, ${ }^{8}$ yttrium(III) eight in a square antiprism, ${ }^{9}$ and lanthanum(III) nine waters in a tricapped trigonal prism. ${ }^{10}$ Thus, even though thallium(III) and indium(III) have larger ionic radii in sixcoordination than $\mathrm{Sc}^{3+}, 0.885,0.800$ and $0.745 \AA{ }^{11}$ respectively, their hydration numbers are smaller. This indicates more covalent bond character for the group 13 metal ions with $\mathrm{d}^{10}$ electron configuration., ${ }^{72}$

The six-coordinated structure of the hydrated aluminium(III) ion is maintained in concentrated aqueous solutions, and large angle X-ray scattering (LAXS) shows mean Al-O bond distances in the range 1.87-1.90 $\AA^{5}$ Structural studies on nonaqueous aluminium(III) solvates do not seem to have been reported so far. The hydrated gallium(III) ion octahedrally coordinates six water molecules, with mean $\mathrm{Ga}-\mathrm{O}$ bond distances reported as 1.944(3) and 1.969(5) $\AA$ in the solid state, ${ }^{13,14}$ and 1.959(6) $\AA$ in aqueous solution. ${ }^{6}$ In crystal structures the hydrated indium(III) ion octahedrally coordinates six water molecules with the In-O bond distances 2.112 and $2.134 \AA{ }^{13}$ and in aqueous solution 2.131(7) $\AA^{6}{ }^{6}$

Few structural investigations have been performed of the dimethyl sulfoxide solvated group 13 metal ions. Even though dimethyl sulfoxide is an ambidentate solvent, coordination via the sulfur atom takes place only for soft metal ions, e.g. palladium(II), platinum(II) and rhodium(III), ${ }^{15}$ and the relatively hard group 13 metal ions are solvated via the oxygen atom. Previously, discrete hexakis(dimethyl sulfoxide)indium(III) and thallium(III) complexes have been crystallographically 
Table 1 Crystallographic data for 1, 2 and 3

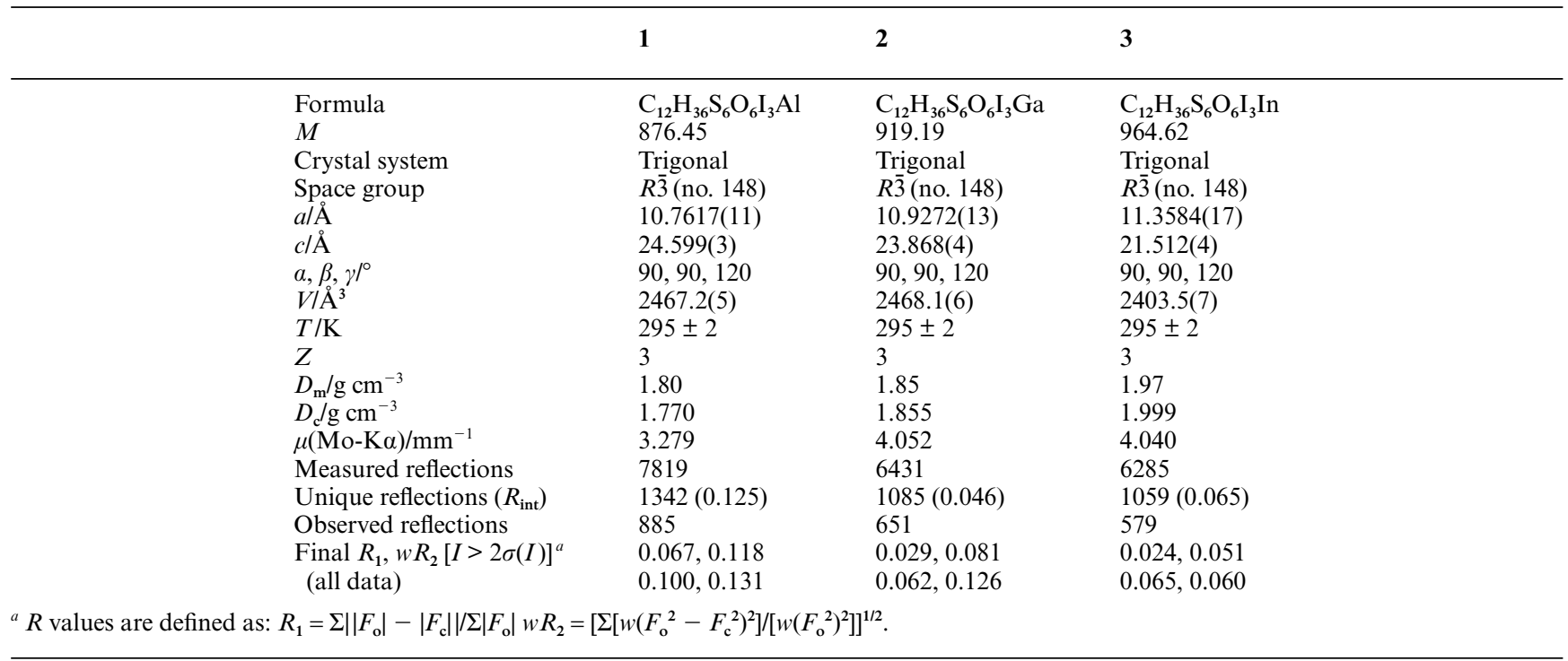

characterized in the perchlorate salts, with $\mathrm{M}-\mathrm{O}$ bond distances of 2.140(3) and 2.224(3) A, respectively. ${ }^{16,17}$ In the current work iodide has been chosen as counter ion to the hexakis(dimethyl sulfoxide) solvates of the aluminium(III), gallium(III) and indium(III) ions in order to avoid the structure determination problems caused by disordered perchlorate ions. ${ }^{16,17}$ Interpretation of the vibrational spectra is also facilitated because the non-coordinated iodide ions give no additional vibrational frequencies. The strength and nature of the metal-oxygen bond and its effect on the dimethyl sulfoxide ligand has been evaluated by normal coordinate analysis and compared with other dimethyl sulfoxide solvates.

\section{Experimental}

\section{Chemicals}

Hexakis(dimethyl sulfoxide)aluminium(III) iodide, 1, hexakis(dimethyl sulfoxide) gallium(III) iodide, 2, and hexakis(dimethyl sulfoxide)indium(III) iodide, 3. Anhydrous group 13 metal iodides (Aldrich) were suspended in dichloromethane, and dimethyl sulfoxide (Merck) was slowly added in six-fold excess. The aluminium and gallium iodides then formed white finecrystalline precipitates of $\mathbf{1}$ and $\mathbf{2}$, respectively. Crystals suitable for X-ray crystallography were obtained after recrystallisation from acetonitrile. Addition of dimethyl sulfoxide to the indium iodide suspension gave a colourless solution, which after evaporation at reduced pressure yielded colourless crystals of $\mathbf{3}$.

Hexakis(dimethyl sulfoxide)gallium(III) and indium(III) perchlorate. Gallium(III) oxide and indium(III) hydroxide were slurried in water and concentrated perchloric acid (AnalR, $70 \%$ ) was added dropwise. The reaction mixture was refluxed for $2 \mathrm{~h}$ until a clear solution formed. After boiling off some of the water the solution was evaporated in a desiccator until hydrated metal(III) perchlorates precipitated. The salts were dissolved in a minimum amount of acetone and then six equivalents of 2,2-dimethoxypropane (Merck), which reacts with water to form methanol and acetone, ${ }^{18}$ were added. ${ }^{19}$ The reaction mixture was stirred vigorously for 5-10 min. When adding a six-fold excess of dimethyl sulfoxide the dimethyl sulfoxide solvates precipitated immediately. The stirring was continued for another 5-10 min before filtering off the crystals. Recrystallisation was performed from dimethyl sulfoxide.

Anhydrous gallium(III) and indium(III) trifluoromethanesulfonate. Gallium(III) oxide and indium(III) hydroxide were slurried in water and trifluoromethanesulfonic acid (Alfa, 100\%) was added dropwise in a fairly large excess. After refluxing for $2 \mathrm{~h}$ clear solutions had formed, which were filtered. Water and excess acid was boiled off at $c a$. $450 \mathrm{~K}$, leaving anhydrous gallium(III) and indium(III) trifluoromethanesulfonate salts. Dimethyl sulfoxide solutions of gallium(III) and indium(III) trifluoromethanesulfonate were prepared by dissolving the hygroscopic anhydrous salts in dimethyl sulfoxide under nitrogen atmosphere. Crystals were obtained by evaporating the solutions under reduced pressure in a desiccator.

\section{X-Ray crystallography}

The data collections were made on small crystals of $\mathbf{1 ,} 2$ and 3 enclosed in thin-walled glass capillaries at room temperature, by means of a STOE imaging-plate diffractometer. ${ }^{20}$ Absorption corrections were performed with the programs X-RED and $\mathrm{X}$-Shape. ${ }^{21}$ Symmetry equivalent reflections were used to optimise crystal shape and size. The structures were solved by direct methods using SHELXS-97, ${ }^{22}$ and refined using the full-matrix least-squares method on $F^{2}$, SHELXL-97. ${ }^{23}$ All non-hydrogen atoms were refined anisotropically. Hydrogen atoms were added at calculated positions and refined using a riding model. Systematic absences for $\mathbf{1}, \mathbf{2}$ and $\mathbf{3}$ in the collected diffraction data were consistent with the space group $R \overline{3}$ (no. 148). Selected crystallographic and experimental details are summarised in Table 1.

CCDC reference numbers 199307-199309.

See http://www.rsc.org/suppdata/dt/b2/b212140a/ for crystallographic data in CIF or other electronic format.

\section{EXAFS}

Gallium and indium $\mathrm{K}$ edge X-ray absorption data were collected in transmission mode at the Stanford Synchrotron Radiation Laboratory (SSRL), USA, under dedicated conditions. The SSRL storage ring operates at $3.0 \mathrm{GeV}$ and a maximum current of $100 \mathrm{~mA}$. A Si[220] double monochromator provided monochromatic radiation in the scan range, detuned to $50 \%$ of maximum intensity at the end of the scans to reduce higher order harmonics.

The solutions were kept in cells with $6.3 \mu \mathrm{m} \mathrm{X}$-ray polypropylene foil windows and $1-5 \mathrm{~mm}$ Teflon spacers. The solids were finely ground and diluted with boron nitride $(\mathrm{BN})$ to prevent self-absorption and pin-hole effects, and to achieve an absorption change over the edge of about one logarithmic unit. Energy calibration of the X-ray absorption spectra was performed by simultaneously recording the edge spectrum of a gallium or indium foil during the data collection, and assigning the first K-edge inflection point of the metal to 10368.2 and 
$27940.0 \mathrm{eV}$, respectively. ${ }^{24}$ After energy calibration, 3-4 scans were averaged for each sample. The EXAFSPAK program package was used for the data treatment. ${ }^{25}$ The EXAFS oscillations were extracted using standard procedures for pre-edge subtraction, spline removal and data normalisation. ${ }^{26,27}$ Model fitting, including both single and multiple back-scattering pathways, was performed with theoretical phase and amplitude functions calculated $a b$ initio using the FEFF7 computer code. $^{28}$ The $k^{3}$-weighted EXAFS oscillation was analysed by a non-linear least-squares fitting procedure of the model parameters.

\section{Raman and infrared spectra}

Raman spectra of the solids 1, 2 and $\mathbf{3}$ were obtained using a Renishaw System 1000 spectrometer, equipped with a Leica DMLM microscope, a $25 \mathrm{~mW}$ diode laser $(782 \mathrm{~nm})$, and a Peltier-cooled CCD detector. The mid-infrared absorption spectra of the solid compounds were obtained by means of a Bio-RAD FTS 6000 FT-IR spectrometer ( $\mathrm{KBr}$ pellet). The farinfrared spectrum was recorded with the sample enclosed in a polyethylene disk. Normal coordinate analyses of the spectra and force field calculations were performed by means of Wilson's GF matrix method. A PC-based program package developed by J. and L. Mink ${ }^{29}$ was used to compute force constants and to fit calculated vibrational frequencies, using a symmetrised valence force field.

\section{Results and discussion}

\section{Crystal structures of 1, 2 and 3}

The crystal structures of $\mathbf{1}, \mathbf{2}$ and $\mathbf{3}$ were satisfactorily described in the space group $R \overline{3}$. The trivalent metal ions were located in a site of $\overline{3}$ symmetry surrounded by six equidistant oxygenbonded dimethyl sulfoxide ligands, Fig. 1 . The $\mathrm{M}-\mathrm{O}$ bond distances 1.894(4), 1.974(4) and 2.145(3) $\AA$ were obtained for the $\left[\mathrm{M}(\mathrm{dmso})_{6}\right]^{3+}$ complexes with $\mathrm{M}=\mathrm{Al}, \mathrm{Ga}$ and In, respectively. The In-O bond distance in the $\left[\mathrm{In}\left(\mathrm{OS}\left(\mathrm{CH}_{3}\right)_{2}\right)_{6}\right] \mathrm{I}_{3}$ complex is in good agreement with that previously found for $\left[\operatorname{In}\left(\mathrm{OS}\left(\mathrm{CH}_{3}\right)_{2}\right)_{6}\right]$ $\left(\mathrm{ClO}_{4}\right)_{3}, 2.140(3) \AA .{ }^{16}$ However, for the mixed ligand [ $\mathrm{InX}_{3}$ $\left(\mathrm{OS}\left(\mathrm{CH}_{3}\right)_{2}\right)_{3}$ ] compounds with $\mathrm{X}=\mathrm{Cl}$ and $\mathrm{Br}$, the $\mathrm{In}-\mathrm{O}$ bond distances became longer, 2.195 and $2.199 \AA$, respectively. ${ }^{30}$ This shows that chloride and bromide as ligands bind more strongly to indium than dimethyl sulfoxide, while iodide is not able to compete with dimethyl sulfoxide for coordination to indium. The non-bonded iodide ions in $\mathbf{1}, \mathbf{2}$ and $\mathbf{3}$, located between the $\left[\mathrm{M}(\mathrm{dmso})_{6}\right]^{3+}$ complexes, are each in contact with 12 methyl groups. The $\mathrm{I}^{-} \cdots \mathrm{C}$ distances are in the range between 3.97 to $4.34 \AA$ for the indium compound, with somewhat smaller spread for the gallium (3.97-4.32 $\AA$ ) and aluminium (4.00-4.30 A) compounds.

All trivalent group 13 metal ions form solvates with six dimethyl sulfoxide ligands, including thallium(III) perchlorate with the T1-O bond distances 2.224(3) A.,Table 2. Of the trivalent $\mathrm{d}^{0}$ ions in group 3 , the scandium(III) iodide forms a hexakis(dimethyl sulfoxide)scandium(III) solvate isostructural with 1, 2 and 3, with an Sc-O bond distance of 2.075(3) $\AA^{31}$ Yttrium(III) and lanthanum(III) coordinate eight dimethyl sulfoxide molecules in a square antiprismatic fashion, with the mean Y-O and La-O bond lengths 2.36(1) and $2.48 \AA{ }^{10,32,33}$ respectively. When comparing yttrium(III) and thallium(III), with similar ionic radii in six-coordination, 0.900 and $0.885 \AA$, ${ }^{11}$ respectively, the stronger tendency to octahedral coordination for the trivalent ions of group 13 is again obvious, as for the hydrates.

For the $\left[\mathrm{M}(\mathrm{dmso})_{6}\right]^{3+}$ complexes with $\mathrm{M}=\mathrm{Al}, \mathrm{Ga}, \mathrm{Sc}$, In and $\mathrm{Tl}$, the $\mathrm{M}-\mathrm{O}$ bond distances increase from 1.894 to $2.224 \AA$ (Table 2). The increasing oxygen-oxygen distances within the $\mathrm{MO}_{6}$ kernel allow substantial deviations from a regular

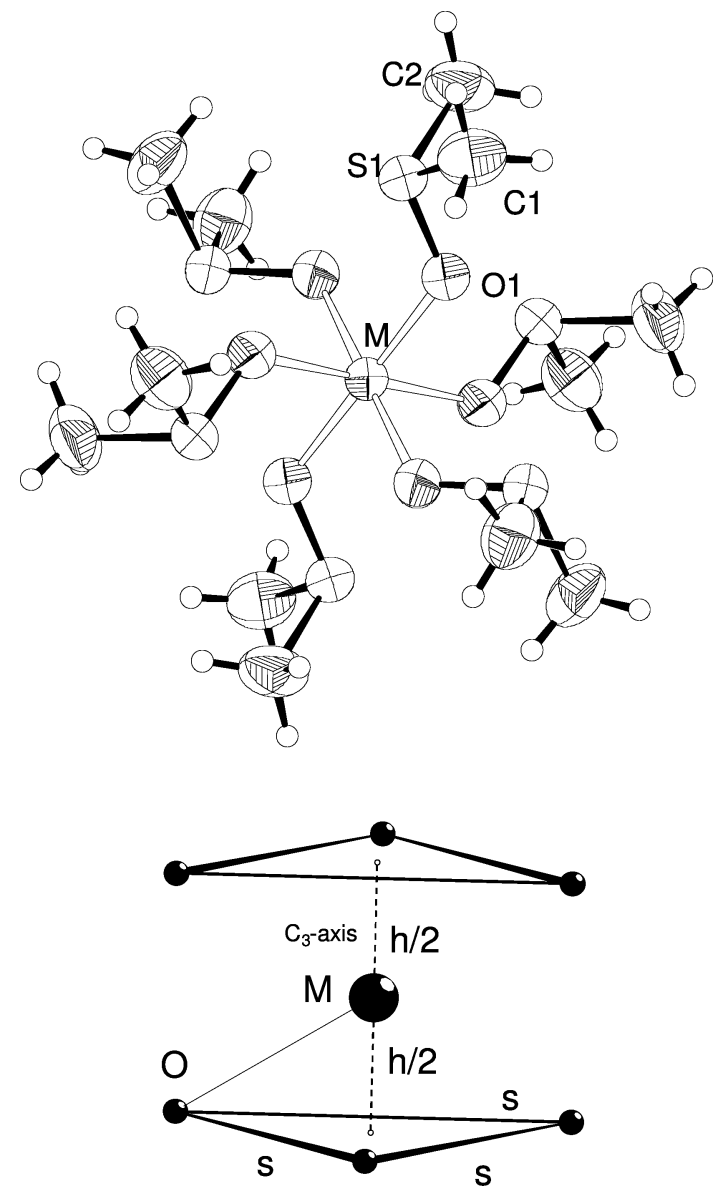

Fig. 1 (Top) The hexakis(dimethyl sulfoxide)-aluminium(III), -gallium(III) or -indium(III) complexes in the isomorphous $\left[\mathrm{M}(\mathrm{dmso})_{6}\right) \mathrm{I}_{3}$ crystal structures. The figure shows the gallium complex with $50 \%$ probability ellipsoids; (bottom) the octahedral $\mathrm{MO}_{6}$ centre in the $\left[\mathrm{M}(\mathrm{dmso})_{6}\right]^{3+}$ structure is compressed along the three-fold axis. For a perfect octahedron $s / h=\sqrt{3} / 2=1.225$, where $s$ is the side of and $h$ is the distance between the equilateral triangular surfaces.

octahedral symmetry for the relatively large indium(III) and thallium(III) ions by compression along the three-fold axis in $\overline{3}$ symmetry. This can be measured by the compression ratio $s / h$ (cf. Fig. 1). The smallest ions, aluminium(III), gallium(III) and scandium(III), have similar compression ratios of about 1.287 in the iodide salts of the hexakis(dimethyl sulfoxide) solvates, while the compression ratio increases to 1.335 for hexakis(dimethyl sulfoxide)indium iodide (Table 2). This is reflected in the cell volume, which for the isostructural iodide solvates is smallest for the largest ion, In(III). A comparison between the isostructural solvated indium(III) and thallium(III) perchlorates shows similar effects, with compression ratios of 1.373 and 1.455, respectively. ${ }^{34}$ Again the larger ion, thallium(III), has the smaller cell volume (Table 2 ).

Despite the difference in $\mathrm{M}-\mathrm{O}$ bond distance the aluminium and gallium iodide structures have quite similar compression ratios and cell volumes, which shows that there are other factors than ionic size to consider. The conformation of the $\left(\mathrm{CH}_{3}\right)_{2} \mathrm{SO}$ ligand in the $\left[\mathrm{M}(\mathrm{dmso})_{6}\right]^{3+}$ complexes, reflected by the $3.0^{\circ}$ larger $\mathrm{M}-\mathrm{O}-\mathrm{S}$ angle for the aluminium solvate ( $c f$. Table 2), also affects the cell volume.

The $\mathrm{M}-\mathrm{O}-\mathrm{S}$ angle is affected to some degree by the covalency of the $\mathrm{M}-\mathrm{O}$ bond. Small angles, below $120^{\circ}$, are found for covalent $\mathrm{M}-\mathrm{O}$ bonds, as e.g. in hexakis(dimethyl sulfoxide)mercury(II) triflate, $116.4(3)^{\circ}$ ( $c f$. Table 2$),{ }^{35}$ while for complexes with low covalency much larger angles are observed, as for hexakis(dimethyl sulfoxide)scandium(III) iodide, $132.5(3)^{\circ}$. The smallest angle $\mathrm{M}-\mathrm{O}-\mathrm{S}$ angle for the hexakis(dimethyl sulfoxide) complexes of the trivalent group 13 metal ions is found for thallium(III), $120.7(2)^{\circ}$, and the largest for aluminium, $127.1(3)^{\circ}$ 
Table 2 Bond lengths $(\AA)$ and angles $\left(^{\circ}\right)$ for $\left[\mathrm{M}(\mathrm{dmso})_{6}\right]^{n+}$ complexes in symmetry

\begin{tabular}{|c|c|c|c|c|c|c|c|c|}
\hline Metal atom & Perchlorate $^{a}$ & $\begin{array}{l}\text { In(III) } \\
\text { Perchlorate }^{b}\end{array}$ & Iodide $^{c}$ & Iodide $^{c}$ & Iodide $^{c}$ & $\begin{array}{l}\text { Sc(III) } \\
\text { Iodide }^{d}\end{array}$ & $\begin{array}{l}\mathrm{Hg}(\mathrm{II}) \\
\text { Triflate }^{e}\end{array}$ & $\begin{array}{l}\text { Uncoordinated } \\
\text { dimethyl sulfoxide }^{f}\end{array}$ \\
\hline $\mathrm{M}-\mathrm{O}$ & $2.224(3)$ & $2.140(3)$ & $2.145(3)$ & $1.974(4)$ & $1.894(4)$ & $2.075(3)$ & $2.347(5)$ & \\
\hline $\begin{array}{l}\text { Compression } \\
\text { ratio } s / h^{g}\end{array}$ & $1.455(3)$ & $1.373(4)$ & $1.335(4)$ & $1.285(6)$ & $1.287(3)$ & $1.287(4)$ & $1.390(6)$ & \\
\hline Cell volume & $2584.0(5)$ & $2622.0(12)^{h}$ & $2403.5(7)$ & $2468.1(6)$ & $2467.2(5)$ & $2507.6(6)$ & $2593.8(6)^{h}$ & \\
\hline $\begin{array}{l}\text { Closest } \mathrm{O} \cdots \mathrm{O} \\
\text { distance }\end{array}$ & $2.948(5)$ & $2.915(5)$ & $2.945(4)$ & $2.746(6)$ & $2.636(5)$ & $2.887(5)$ & $3.182(7)$ & \\
\hline $\mathrm{O}-\mathrm{S}$ & $1.544(4)$ & $1.542(3)$ & $1.541(3)$ & $1.539(5)$ & $1.540(5)$ & $1.530(3)$ & $1.543(5)$ & $1.495(4)$ \\
\hline $\mathrm{S}-\mathrm{C}(1)$ & $1.758(8)$ & $1.763(8)$ & $1.787(5)$ & $1.773(8)$ & $1.776(7)$ & $1.761(5)$ & $1.766(8)$ & $1.773(4)$ \\
\hline $\mathrm{S}-\mathrm{C}(2)$ & $1.770(7)$ & $1.771(6)$ & $1.765(5)$ & $1.774(8)$ & $1.776(8)$ & $1.769(5)$ & $1.764(9)$ & \\
\hline $\mathrm{O}-\mathrm{M}-\mathrm{O}^{\prime}$ & $96.20(13)$ & $94.2(1)$ & $93.3(1)$ & $91.8(2)$ & $91.9(2)$ & $91.9(2)$ & $94.6(2)$ & \\
\hline $\mathrm{M}-\mathrm{O}-\mathrm{S}$ & $120.7(2)$ & $124.0(2)$ & $123.1(2)$ & $124.1(3)$ & $127.1(3)$ & $132.5(2)$ & $116.4(3)$ & \\
\hline $\mathrm{O}-\mathrm{S}-\mathrm{C}(1)$ & $103.2(3)$ & $102.9(2)$ & $104.1(2)$ & $104.6(4)$ & $104.0(3)$ & $103.7(2)$ & $104.1(3)$ & $105.7(2)$ \\
\hline $\mathrm{O}-\mathrm{S}-\mathrm{C}(2)$ & $104.2(3)$ & $103.6(3)$ & $103.3(2)$ & $102.9(3)$ & $102.6(3)$ & $103.8(2)$ & $106.5(4)$ & \\
\hline $\mathrm{C}(1)-\mathrm{S}-\mathrm{C}(2)$ & $99.8(4)$ & $99.6(3)$ & $98.5(3)$ & $98.3(4)$ & $98.4(4)$ & $98.9(3)$ & $98.6(5)$ & $98.0(3)$ \\
\hline
\end{tabular}

${ }^{a}$ Ref. 17. ${ }^{b}$ Ref. $16 .{ }^{c}$ This work. ${ }^{d}$ Ref. $31 .{ }^{e}$ Ref. $35 .{ }^{f}$ Mean values for uncoordinated dimethyl sulfoxide molecules in crystals, ref. $15 .{ }^{g}$ Ref. 34 ; $s / h=1.225$ for a regular octahedron. ${ }^{h}$ With hexagonal unit cell $(Z=3)$.

Table 3 Bond distances, $d / \AA$, Debye-Waller factors, $\sigma^{2} / \AA^{2}$, and number of distances, $n$, of the dimethyl sulfoxide solvated gallium(III) and indium(III) ions as determined by EXAFS at room temperature; $E_{\mathrm{o}} / \mathrm{eV}$ is the refined threshold energy and $S_{\mathrm{o}}{ }^{2}$ the refined amplitude reduction factor

\begin{tabular}{|c|c|c|c|c|c|c|}
\hline State & & $d$ & $\sigma^{2}$ & $n$ & $E_{\mathrm{o}}$ & $S_{\mathrm{o}}^{2}$ \\
\hline $0.25 \mathrm{M} \mathrm{Ga}\left(\mathrm{ClO}_{4}\right)_{3}$ in $\mathrm{Me}_{2} \mathrm{SO}$ solution & $\begin{array}{l}\mathrm{Ga}-\mathrm{O} \\
\mathrm{Ga} \cdots \mathrm{S} \\
\mathrm{Ga}-\mathrm{O}-\mathrm{S} \\
\mathrm{MS}\end{array}$ & $\begin{array}{l}1.955(2) \\
3.108(4) \\
3.194(18) \\
3.964(14)\end{array}$ & $\begin{array}{l}0.0065(2) \\
0.0112(6) \\
0.019(4) \\
0.0054(20)\end{array}$ & $\begin{array}{c}6 \\
6 \\
12 \\
3 \times 6\end{array}$ & $10378.0(3)$ & $1.27(3)$ \\
\hline Solid $\left[\mathrm{Ga}(\mathrm{dmso})_{6}\right]\left(\mathrm{CF}_{3} \mathrm{SO}_{3}\right)_{3}$ & $\begin{array}{l}\mathrm{Ga}-\mathrm{O} \\
\mathrm{Ga} \cdots \mathrm{S} \\
\mathrm{Ga}-\mathrm{O}-\mathrm{S} \\
\mathrm{MS}\end{array}$ & $\begin{array}{l}1.954(2) \\
3.117(3) \\
3.280(23) \\
3.982(25)\end{array}$ & $\begin{array}{l}0.0050(2) \\
0.0079(4) \\
0.015(4) \\
0.0080(40)\end{array}$ & $\begin{array}{c}6 \\
6 \\
12 \\
3 \times 6\end{array}$ & 10379.3 & $1.19(4)$ \\
\hline $1.00 \mathrm{M} \mathrm{In}\left(\mathrm{CF}_{3} \mathrm{SO}_{3}\right)_{3}$ solution & $\begin{array}{l}\text { In-O } \\
\text { In } \cdots \text { S } \\
\text { In-O-S } \\
\text { MS }\end{array}$ & $\begin{array}{l}2.135(2) \\
3.320(6) \\
3.481(9) \\
4.19(3)\end{array}$ & $\begin{array}{l}0.0054(2) \\
0.0094(5) \\
0.0036(9) \\
0.011(5)\end{array}$ & $\begin{array}{c}6 \\
6 \\
12 \\
3 \times 6\end{array}$ & $27949.0(4)$ & $1.03(3)$ \\
\hline Solid $\left[\operatorname{In}(\text { dmso })_{6}\right]\left(\mathrm{ClO}_{4}\right)_{3}$ & $\begin{array}{l}\text { In-O } \\
\text { In } \cdots \text { S } \\
\text { In-O-S } \\
\text { MS }\end{array}$ & $\begin{array}{l}2.143(2) \\
3.282(3) \\
3.519(11) \\
4.35(7)\end{array}$ & $\begin{array}{l}0.0043(2) \\
0.0071(3) \\
0.012(2) \\
0.034(20)\end{array}$ & $\begin{array}{c}6 \\
6 \\
12 \\
3 \times 6\end{array}$ & 27951.9 & $0.96(3)$ \\
\hline
\end{tabular}

(Table 2). The $\mathrm{S}-\mathrm{O}$ distance of the $\mathrm{O}$-coordinated dimethyl sulfoxide ligands is, however, almost constant at about $1.54 \AA$, which is almost $0.05 \AA$ longer than in the free dimethyl sulfoxide molecule, $c f$. Table 2 .

\section{EXAFS Studies}

Dimethyl sulfoxide solvates of gallium(III) and indium(III). EXAFS data for the dimethyl sulfoxide solvated gallium(III) and indium(III) ions in the solid state and solution were collected with different anions, perchlorate and trifluoromethanesulfonate. The results (Table 3 ) show that the structures of the hexakis(dimethyl sulfoxide)gallium(III) and indium(III) complexes are insensitive to the counter-ions. The bond distances were modelled with the main contributions from $\mathrm{M}-\mathrm{O}$ and $\mathrm{M} \cdots \mathrm{S}$ single backscattering, and the three-legged $\mathrm{M}-\mathrm{O}-\mathrm{S}$ backscattering pathways ( $c f$. Fig. S2, ESI $\dagger$ ). The fit of the model improved for both solutions and solids by introducing the linear $\mathrm{M}-\mathrm{O}-\mathrm{O}$ and $\mathrm{M}-\mathrm{O}-\mathrm{M}-\mathrm{O}$ multiple scattering pathways (multiplicity $3 \times 6$ ) within the octahedral $\mathrm{MO}_{6}$ core at twice the $\mathrm{M}-\mathrm{O}$ bond distance. Figs. 2 and 3 show the fit of the EXAFS model functions, and Figs. 4 and 5 the corresponding Fourier transforms with the refined parameter values listed in Table 3 for the dimethyl sulfoxide solvated gallium(III) and indium(III) ions, respectively. Least-squares refinement gave the

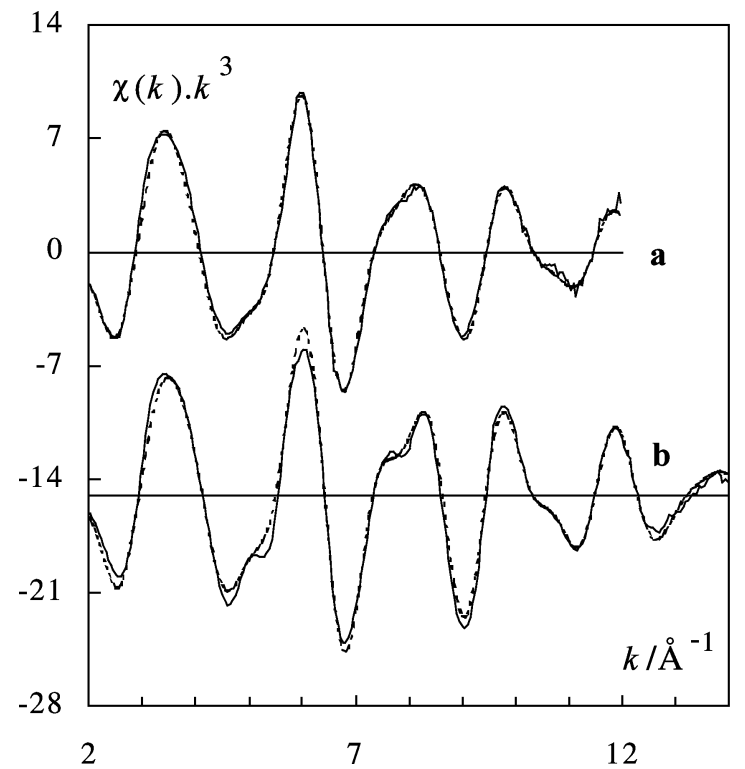

Fig. 2 The EXAFS data and model fit of the (a) dimethyl sulfoxide solution of gallium(III) perchlorate, (b) solid hexakis(dimethyl sulfoxide)gallium(III) trifluoromethanesulfonate, solid line - experimental data, dashed line - calculated model function with the parameters in Table 3 . 


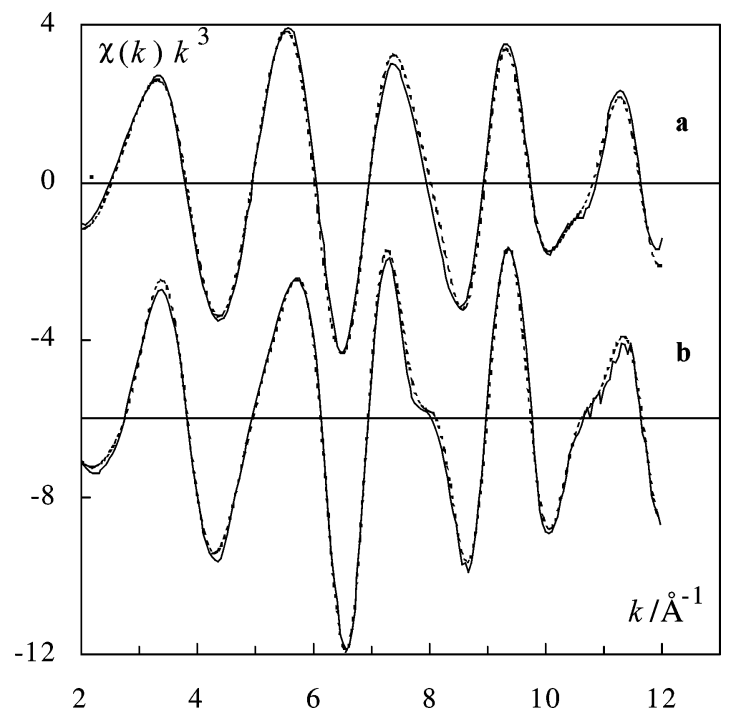

Fig. 3 The EXAFS data and model fit of the (a) dimethyl sulfoxide solution of indium(III) trifluoromethanesulfonate, (b) solid hexakis(dimethyl sulfoxide)indium(III) perchlorate, solid line - experimental data, dashed line - calculated model function with the parameters in Table 3.

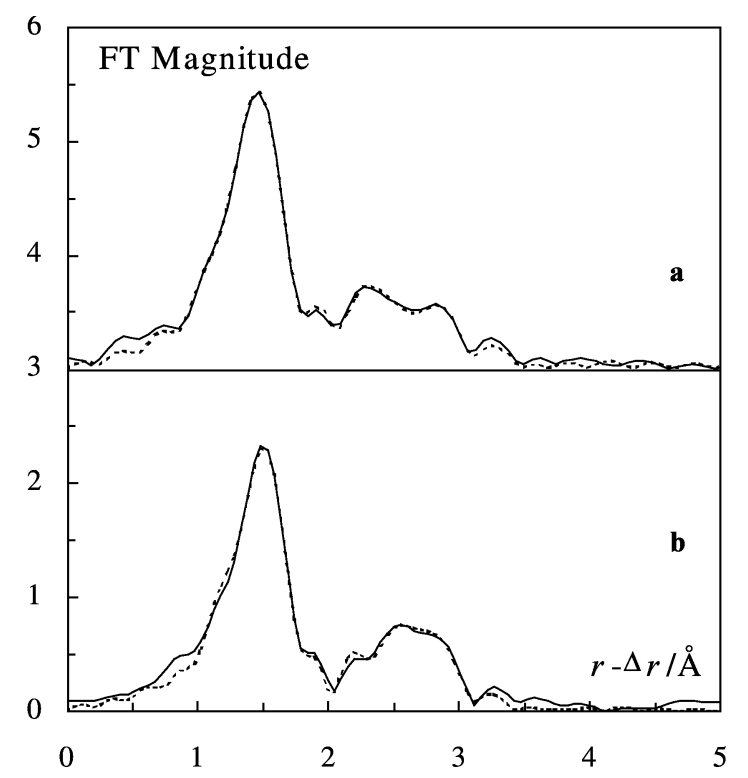

Fig. 4 Fourier transforms (FTs) for the EXAFS data of (a) dimethyl sulfoxide solution of gallium(III) perchlorate, (b) solid hexakis(dimethyl sulfoxide)gallium(III) trifluoromethanesulfonate, solid line - experimental data, dashed line - model function ( $c f$. Fig. 2).

mean $\mathrm{Ga}-\mathrm{O}$ and $\mathrm{Ga} \cdots \mathrm{S}$ distances 1.955(2) and 3.108(4) $\AA$ of the dimethyl sulfoxide solvated gallium(III) in solution, and 1.954(2) and 3.117(3) $\AA$ in solid hexakis(dimethyl sulfoxide)gallium(III) trifluoromethanesulfonate. This corresponds to similar $\mathrm{Ga}-\mathrm{O}-\mathrm{S}$ bond angles, $125.2(5)$ and $125.9(4)^{\circ}$, respectively. The above $\mathrm{Ga}-\mathrm{O}$ bond distances are significantly shorter than in 2, 1.974(4) $\AA$, but in close agreement with $\mathrm{Ga}-\mathrm{O}$ bond distances obtained for hexaaqua solvates in aqueous solution and the solid state. ${ }^{6}$ The mean In-O and In $\cdots$ S distances of 2.135(2) and 3.320(6) $\AA$, and 2.143(2) and 3.282(3) $\AA$ in the dimethyl sulfoxide solvated indium(III) ion in solution and in the solid hexakis(dimethyl sulfoxide)indium(III) perchlorate (Table 3), give In-O-S bond angles of 128.5(6) and 125.2(4) respectively. The In $\cdots$ S distances are significantly longer than the crystallographic value for the iodide $3,3.252(1) \AA$, while the Ga $\cdots$ S distances in 2, 3.110(2) $\AA$, are similar.

The EXAFS values for the In-O bond distances are similar to those in 3, 2.145(3) $\AA$, and in hexakis(dimethyl sulfoxide)indium(III) perchlorate (Tables 2 and 3$),{ }^{16}$ and are also in

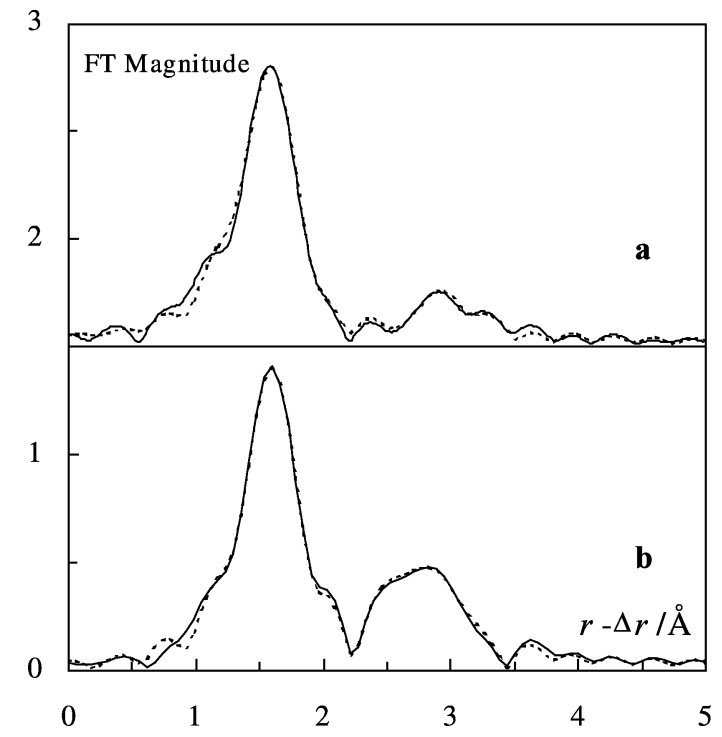

Fig. 5 Fourier transforms (FTs) for the EXAFS data of (a) dimethyl sulfoxide solution of indium(III) trifluoromethanesulfonate, (b) solid hexakis(dimethyl sulfoxide)indium(III) perchlorate, solid line - experimental data, dashed line- model function ( $c f$. Fig. 3)

agreement with the In-O bond distances observed in hexaaqua solvates in both aqueous solution and the solid state. ${ }^{6}$ The relatively small and similar Debye-Waller factors $\left(\sigma^{2} / \AA^{2}\right)$ indicate small deviations from the mean $\mathrm{M}-\mathrm{O}$ bond distances in the hexaaqua- and hexakis(dimethyl sulfoxide)-gallium(III) and -indium(III) ions both in the solid state and solution ( $c f$. ref. 6 and Table 3).

\section{Vibrational spectra and force constant calculations}

Raman and infrared spectra were recorded for compounds $\mathbf{1 , 2}$ and 3, and the Raman spectra are displayed between 100 and $600 \mathrm{~cm}^{-1}$ in Fig. 6. A force field study was undertaken of the vibrational spectra to allow comparisons of the metal-oxygen bond character and how the coordination affects the dimethyl sulfoxide ligands. The centrosymmetric $\mathrm{M}(\mathrm{dmso})_{6}{ }^{3+}$ complexes can be described in the $S_{6}$ point group, with the normal vibrations belonging to the symmetry species $11 \mathrm{~A}_{\mathrm{g}}+11 \mathrm{E}_{\mathrm{g}}+12 \mathrm{~A}_{\mathrm{u}}$ $+12 \mathrm{E}_{\mathrm{u}}$, considering the methyl groups as point masses. All symmetric modes are Raman-active whereas the asymmetric ones are IR-active.

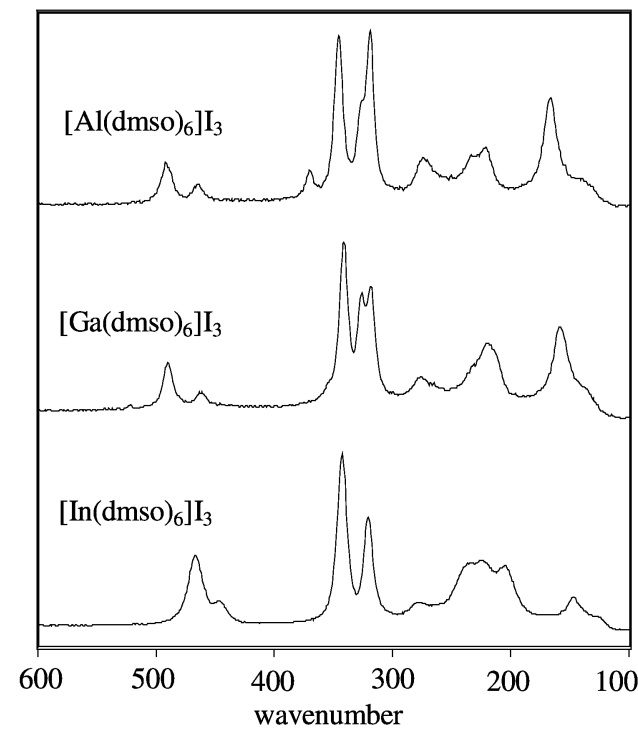

Fig. 6 Raman spectra for solid hexakis(dimethyl sulfoxide)aluminium(III), -gallium(III) and -indium(III) iodide (Renishaw System 1000 spectrometer with Leica DMLM microscope and diode laser, 782 $\mathrm{nm}$ ). 
Table 4 Observed and calculated frequencies $\left(\mathrm{cm}^{-1}\right)$ and potential energy distribution (PED) for $\mathrm{M}(\mathrm{dmso})_{6}{ }^{3+} \mathrm{complexes}(\mathrm{M}=\mathrm{Al}, \mathrm{Ga}, \mathrm{In}$ and $\mathrm{Tl})$

\begin{tabular}{|c|c|c|c|c|c|c|}
\hline $\mathrm{Al}(\mathrm{dm}$ & & $\mathrm{Ga}\left(\mathrm{d}_{1}\right.$ & )$_{6}^{3+}$ & $\mathrm{In}(\mathrm{dm}$ & & $\mathrm{Tl}(\mathrm{dm}$ \\
\hline Obs. $^{a}$ & Calc. & Obs. $^{a}$ & Calc. & Obs. $^{a}$ & Calc. & Obs. $^{a}$ \\
\hline
\end{tabular}

\begin{tabular}{lrrrrrrr}
\hline $\mathrm{A}_{\mathrm{g}}$ & & & & & & & \\
923 & 923 & 912 & 912 & 916 & 915 & 895 & 897 \\
724 & 724 & 726 & 726 & 723 & 723 & 721 & 722 \\
691 & 691 & 690 & 690 & 685 & 685 & 683 & 681 \\
465 & 467 & 491 & 490 & 444 & 442 & 435 & 428 \\
346 & 346 & 341 & 341 & 345 & 346 & 342 & 342 \\
319 & 323 & 318 & 315 & 321 & 315 & 316 & 309 \\
220 & 213 & 217 & 214 & 215 & 207 & 218 & 209 \\
154 & 145 & 129 & 122 & 120 & 115 & 136 & 122 \\
& 122 & & 106 & & 101 & 117 & 100 \\
& 42 & & 38 & & 36 & & 35 \\
& 22 & & 23 & & 23 & & 23
\end{tabular}

$\begin{array}{ll}86 v_{\mathrm{s}}(\mathrm{SO}), 10 v_{\mathrm{s}}(\mathrm{MO}) & \mathrm{SO} \text { str. } \\ 98 v_{\mathrm{a}}(\mathrm{CS}) & \mathrm{SC}_{2} \text { asym. str. } \\ 94 v_{\mathrm{s}}(\mathrm{CS}) & \mathrm{SC}_{2} \text { sym. str. } \\ 47 v_{\mathrm{s}}(\mathrm{MO}), 37 \delta_{\mathrm{s}}(\mathrm{CSO}) & \mathrm{MO} \text { sym. str. } \\ 94 \delta_{\mathrm{s}}(\mathrm{CSC}) & \mathrm{SC}_{2} \text { scissor } \\ 61 \delta_{\mathrm{a}}(\mathrm{CSO}), 17 \mathrm{X}_{\mathrm{s}}, 13 \delta_{\mathrm{s}}(\mathrm{CSO}) & \mathrm{SC}_{2} \text { twist } \\ 48 \delta_{\mathrm{s}}(\mathrm{CSO}), 22 v_{\mathrm{s}}(\mathrm{MO}), 13 \delta_{\mathrm{a}}(\mathrm{CSO}), 6 \delta_{\mathrm{s}}(\mathrm{MOS}) & \mathrm{SC}_{2} \text { wag } \\ 73 \delta_{\mathrm{s}}(\mathrm{MOS}), 17 v_{\mathrm{s}}(\mathrm{MO}) & \mathrm{MOS} \text { sym. def. }\end{array}$

$\begin{array}{lrrrrrrr}\mathrm{E}_{\mathrm{g}} & & & & & & & \\ 948 & 948 & 923 & 923 & 916 & 916 & 913 & 916 \\ 724 & 724 & 726 & 726 & 723 & 723 & 721 & 722 \\ 691 & 691 & 690 & 690 & 685 & 686 & 683 & 681 \\ 491 & 491 & 491 & 491 & 444 & 450 & 435 & 435 \\ 346 & 346 & 341 & 342 & 345 & 346 & 342 & 342 \\ 327 & 325 & 318 & 327 & 321 & 327 & 316 & 320 \\ 233 & 227 & 217 & 220 & 215 & 214 & 218 & 211 \\ 167 & 159 & 158 & 143 & 145 & 135 & 136 & 131 \\ & 111 & & 105 & & 102 & 117 & 100 \\ & 37 & & 27 & & 26 & & 26 \\ & 23 & & 24 & & 23 & & 23\end{array}$

$\begin{array}{lrrr}\mathrm{A}_{\mathbf{u}} & & & \\ 898 & 894 & 898 & 898 \\ 725 & 725 & 725 & 725 \\ 689 & 689 & 689 & 689 \\ 540 & 524 & 495 & 487 \\ 346 & 346 & 357 & 356 \\ 322 & 320 & 340 & 345 \\ 234 & 228 & 243 & 247 \\ 171 & 166 & 211 & 210 \\ & 102 & & 130 \\ & 38 & & 41 \\ & 21 & & 20 \\ & 20 & & 18\end{array}$

$\begin{array}{rrrr}903 & 904 & 897 & 910 \\ 714 & 714 & 718 & 719 \\ 680 & 681 & 686 & 687 \\ 440 & 441 & 447 & 443 \\ 350 & 348 & 344 & 346 \\ 333 & 336 & 319 & 322 \\ 241 & 225 & 216 & 218 \\ 175 & 175 & 157 & 138 \\ & 124 & 115 & 116 \\ & 38 & & 34 \\ & 19 & & 19 \\ & 18 & & 18\end{array}$

$\begin{array}{lr}\mathrm{E}_{\mathbf{u}} & \\ 898 & 900 \\ 725 & 725 \\ 689 & 689 \\ 520 & 519 \\ 346 & 346 \\ 322 & 320 \\ 234 & 241 \\ 171 & 166 \\ & 111 \\ & 29 \\ & 22 \\ & 20\end{array}$

$\begin{array}{rr}898 & 898 \\ 725 & 725 \\ 689 & 689 \\ 495 & 502 \\ 357 & 356 \\ 327 & 323 \\ 262 & 269 \\ 211 & 195 \\ & 108 \\ & 36 \\ & 26 \\ & 18\end{array}$

$86 v_{\mathrm{s}}(\mathrm{SO}), 10 v_{\mathrm{s}}(\mathrm{MO})$

$98 v_{\mathrm{a}}(\mathrm{CS})$

$96 v_{\mathrm{s}}(\mathrm{CS})$

$46 v_{\mathrm{s}}(\mathrm{MO}), 37 \delta_{\mathrm{s}}(\mathrm{CSO}), 13 \delta_{\mathrm{s}}(\mathrm{MOS})$

$92 \delta_{\mathrm{s}}(\mathrm{CSC})$

$57 \delta_{\mathrm{a}}(\mathrm{CSO}), 28 \mathrm{X}_{\mathrm{s}}, 7 \delta_{\mathrm{s}}(\mathrm{CSO})$

$52 \delta_{\mathrm{s}}(\mathrm{CSO}), 18 v_{\mathrm{s}}(\mathrm{MO}), 6 \delta_{\mathrm{s}}(\mathrm{CSO})$

$25 \delta_{\mathrm{s}}(\mathrm{MOS}), 18 \mathrm{X}_{\mathrm{s}}, 16 v_{\mathrm{s}}(\mathrm{MO}), 11 \delta_{\mathrm{a}}(\mathrm{CSO})$
SO str.

$\mathrm{SC}_{2}$ asym. str.

$\mathrm{SC}_{2}$ sym. str.

MO sym. str.

$\mathrm{SC}_{2}$ scissor

$\mathrm{SC}_{2}$ twist

$\mathrm{SC}_{2}$ wag

MOS sym. def.
$85 v_{\mathrm{a}}(\mathrm{SO}), 10 v_{\mathrm{a}}(\mathrm{MO})$

$98 v_{\mathrm{a}}(\mathrm{CS})$

$92 v_{\mathrm{s}}(\mathrm{CS})$

$43 v_{\mathrm{a}}(\mathrm{MO}), 30 \delta_{\mathrm{a}}(\mathrm{CSO}), 22 \delta_{\mathrm{s}}(\mathrm{CSO})$

$83 \delta_{\mathrm{s}}(\mathrm{CSC})$

$53 \delta_{\mathrm{a}}(\mathrm{CSO}), 31 \mathrm{X}_{\mathrm{a}}$

$44 \delta_{\mathrm{s}}(\mathrm{CSO}), 29 v_{\mathrm{a}}(\mathrm{MO}), 18 \delta_{\mathrm{a}}(\mathrm{CSO})$

$42 \delta_{\mathrm{a}}(\mathrm{MOS}), 31 \delta_{\mathrm{a}}(\mathrm{CSO})$
SO str.

$\mathrm{SC}_{2}$ asym. str.

$\mathrm{SC}_{2}$ sym. str.

MO asym. str.

$\mathrm{SC}_{2}$ scissor

$\mathrm{SC}_{2}$ twist

$\mathrm{SC}_{2}$ wag

MOS asym. def.

${ }^{a}$ Raman value.

The experimental and calculated frequencies of the fundamental modes for compounds $\mathbf{1 ,} \mathbf{2}$ and $\mathbf{3}$ are given in Table 4, together with values from a corresponding analysis made for $\left[\mathrm{Tl}(\mathrm{dmso})_{6}\right]\left(\mathrm{ClO}_{4}\right)_{3}$. We performed a normal coordinate analysis for pure dimethyl sulfoxide that enabled us to assign new bands in the region $400-600 \mathrm{~cm}^{-1}$ to $\mathrm{M}-\mathrm{O}$ stretching modes; ${ }^{36}$ for $\mathrm{Al}(\mathrm{dmso})_{6}{ }^{3+} 465\left(\mathrm{~A}_{\mathrm{g}}\right), 491\left(\mathrm{E}_{\mathrm{g}}\right), 540\left(\mathrm{~A}_{\mathrm{u}}\right)$ and $520\left(\mathrm{E}_{\mathrm{u}}\right) \mathrm{cm}^{-1}$; for $\mathrm{Ga}(\mathrm{dmso})_{6}{ }^{3+} 491\left(\mathrm{~A}_{\mathrm{g}}, \mathrm{E}_{\mathrm{g}}\right)$ and $495\left(\mathrm{~A}_{\mathrm{u}}, \mathrm{E}_{\mathrm{u}}\right) \mathrm{cm}^{-1}$ and for $\mathrm{In}(\mathrm{dmso})_{6}{ }^{3+} 444\left(\mathrm{~A}_{\mathrm{g}}, \mathrm{E}_{\mathrm{g}}\right)$ and $440\left(\mathrm{~A}_{\mathrm{u}}, \mathrm{E}_{\mathrm{u}}\right) \mathrm{cm}^{-1}$. The observable splitting between the $\mathrm{M}-\mathrm{O}$ stretching modes for $\mathrm{Al}(\mathrm{dmso})_{6}{ }^{3+}$ results from a significant vibrational coupling with $\mathrm{CSO}$ skeletal deformational modes of the ligand, which is clearly demonstrated by the potential energy distribution of the Al-O stretching modes. The $\mathrm{AlO}$ and $\mathrm{SO}$ stretch-stretch interaction terms (Table 5), which are out of sequence especially for the trans-direction, provide another explanation of the specific vibrational behaviour of the aluminium solvate.

The $\mathrm{M}-\mathrm{O}$ force constants for the $\mathrm{M}(\mathrm{dmso})_{6}{ }^{3+}$ complexes, $\mathrm{M}=\mathrm{Al}, \mathrm{Ga}$, In and $\mathrm{Tl}$, decrease with increasing MO distance (cf. Tables 2 and 5, Fig. S7). The S-O stretching frequency of the dimethyl sulfoxide ligand is strongly affected by the coordination. The vibrational mode at about $954 \mathrm{~cm}^{-1}$ for free dimethyl sulfoxide, shown by the potential energy distribution to be dominated by the SO stretching, shifts to lower frequencies when coordinated via the oxygen atom, $c f$. Table $4 .{ }^{37}$ Even though no significant difference is observed between the $\mathrm{S}-\mathrm{O}$ bond distances in the $\mathrm{M}(\mathrm{dmso})_{6}{ }^{3+}$ complexes, $\mathrm{M}=\mathrm{Al}, \mathrm{Ga}$, In and $\mathrm{Tl}$ (Table 2), the $\mathrm{S}-\mathrm{O}$ stretching force constants increase in the $\mathrm{Ga}$, In and $\mathrm{Tl}$ series as a consequence of the decreasing metal-oxygen bond strength. The $\mathrm{Al}(\mathrm{dmso})_{6}{ }^{3+}$ complex 
Table 5 Calculated force constants for $\mathrm{M}(\mathrm{dmso})_{6}{ }^{3+}$ complexes $(\mathrm{M}=\mathrm{Al}$, $\mathrm{Ga}$, In and $\mathrm{Tl})$

\begin{tabular}{|c|c|c|c|c|c|c|}
\hline Coordinates & dmso & $\mathrm{Al}(\mathrm{dmso})_{6}{ }^{3+}$ & $\mathrm{Ga}(\mathrm{dmso})_{6}{ }^{3+}$ & $\operatorname{In}(\mathrm{dmso})_{6}{ }^{3+}$ & $\mathrm{Tl}(\mathrm{dmso})_{6}{ }^{3+}$ & Units \\
\hline \multicolumn{7}{|l|}{ Stretching } \\
\hline$K(\mathrm{MO})$ & & $1.761(1.779)$ & $1.617(1.670)$ & $1.318(1.552)$ & $1.300(1.469)$ & $\mathrm{a}^{a}$ \\
\hline$K(\mathrm{OS})$ & 5.061 & $4.599(4.805)$ & $4.168(4.652)$ & $4.274(4.758)$ & $4.279(4.809)$ & $\mathrm{a}^{a}$ \\
\hline$K(\mathrm{CS})$ & 2.063 & 2.500 & 2.519 & 2.495 & 2.471 & $\mathrm{a}$ \\
\hline \multicolumn{7}{|l|}{ Stretch-stretch } \\
\hline$F(\mathrm{MO}, \mathrm{MO})$ trans & & -0.171 & 0.448 & 0.184 & 0.071 & $\mathrm{a}$ \\
\hline$F(\mathrm{MO}, \mathrm{MO}) c i s$ & & -0.048 & 0.007 & 0.003 & 0.012 & $\mathrm{a}$ \\
\hline$F(\mathrm{OS}, \mathrm{OS})$ trans & & -0.124 & 0.012 & 0.024 & -0.034 & $\mathrm{a}$ \\
\hline$F(\mathrm{OS}, \mathrm{OS}) c i s$ & & -0.031 & -0.018 & -0.001 & -0.032 & $\mathrm{a}$ \\
\hline$F(\mathrm{CS}, \mathrm{CS})$ & 0.228 & -0.037 & -0.019 & -0.016 & -0.012 & $\mathrm{a}$ \\
\hline \multicolumn{7}{|l|}{ Bending } \\
\hline$H\left(\mathrm{SC}_{2}\right)$ & 1.522 & 0.968 & 1.057 & 0.953 & 0.874 & $\mathrm{~b}$ \\
\hline$H(\mathrm{OSC})$ & 1.070 & 0.664 & 0.367 & 0.396 & 0.134 & $\mathrm{~b}$ \\
\hline$\tau(\operatorname{MOSC})$ & & 0.134 & 0.145 & 0.148 & 0.134 & $\mathrm{~b}$ \\
\hline \multicolumn{7}{|l|}{ Bend-bend } \\
\hline \multicolumn{7}{|l|}{ Stretch-bend } \\
\hline
\end{tabular}

Units: a: $\mathrm{N} \mathrm{cm}^{-1} ; \mathrm{b}: 10^{-16} \mathrm{~N} \mathrm{~m} \mathrm{rad}{ }^{-2} ; \mathrm{c}: 10^{-6} \mathrm{~N} \mathrm{rad}^{-1}$. ${ }^{a}$ The $\mathrm{MO}$ and OS stretching force constants within parentheses have been obtained using a $\mathrm{M}-\mathrm{OS}\left(\mathrm{CH}_{3}\right)_{2}$ simplified monoligand model.

deviates from this trend and also has a larger $\mathrm{M}-\mathrm{O}-\mathrm{S}$ angle (Table 2).

The $\mathrm{S}-\mathrm{C}$ bond lengths of the free and coordinated dimethyl sulfoxide molecules are similar (Table 2). However, the S-C stretching force constants show a clear increase for the complexes, about $20-22 \%$ higher than for liquid dimethyl sulfoxide. For the $\mathrm{Ga}$, In and $\mathrm{Tl}$ complexes a slightly decreasing $\mathrm{S}-\mathrm{C}$ force constant can be correlated to the increasing SO bond strength (Table 5).

\section{Conclusions}

All the trivalent group 13 ions, aluminium(III), gallium(III), indium(III) and thallium(III), coordinate six dimethyl sulfoxide molecules, both in solution and in the solid solvates. Crystallographic results show the metal ions to be surrounded by six oxygen-bonded dimethyl sulfoxide ligands, forming an octahedral $\mathrm{MO}_{6}$ entity compressed along a three-fold axis, with the highest compression ratios for the largest metal ions (Table 2).

Vibrational spectra of the solvated aluminium(III), gallium(III) and indium(III) ions in the $\left[\mathrm{M}(\mathrm{dmso})_{6}\right]_{3}$ compounds have been recorded and analysed. Symmetric and asymmetric $\mathrm{M}-\mathrm{O}$ stretching modes were found to dominate the vibrational frequencies at 465 and $540 \mathrm{~cm}^{-1}$ for the aluminium, 491 and 495 $\mathrm{cm}^{-1}$ for the gallium, and at 444 and $440 \mathrm{~cm}^{-1}$ for the indium complexes, respectively. Previously, the corresponding normal modes for $\mathrm{Tl}(\mathrm{dmso})_{6}{ }^{3+}$ were found at 435 and $447 \mathrm{~cm}^{-1}$. The S-O stretching force constant of the dimethyl sulfoxide ligand increases for the $\mathrm{d}^{\mathbf{1 0}}$ ions $\mathrm{M}=\mathrm{Ga}$, In and $\mathrm{Tl}$ in the $\mathrm{M}(\mathrm{dmso})_{6}{ }^{3+}$ complexes, as expected from the decreasing $\mathrm{M}-\mathrm{O}$ bond strength (Table 5). However, the $\mathrm{S}-\mathrm{O}$ force constant for the $\mathrm{Al}(\mathrm{dmso})_{6}{ }^{3+}$ complex is higher and differs significantly from this trend even though the $\mathrm{S}-\mathrm{O}$ bond distance is similar. This is probably connected to a more ionic $\mathrm{M}-\mathrm{O}$ bond character of the $\mathrm{d}^{0}$ ions $\mathrm{Al}(\mathrm{III})$ and $\mathrm{Sc}(\mathrm{III})$, which is also reflected in larger $\mathrm{M}-\mathrm{O}-\mathrm{S}$ angles (Table 2).

\section{Acknowledgements}

We gratefully acknowledge the Swedish Research Council, the Wenner-Gren Foundations and the Hungarian National Research Foundation (OTKA T025278) for financial support. $\mathrm{X}$-Ray absorption measurements were carried out at Stanford
Synchrotron Radiation Laboratory (SSRL), a national user facility operated by Stanford University on behalf of the U.S. Department of Energy, Office of Basic Energy Sciences. The Swedish Foundation for International Cooperation in Research and Higher Education (STINT) is acknowledged for grants towards travel expenses and the Swedish Institute for support through the Visby programme.

\section{References}

1 F. H. Allen, S. Bellard, M. D. Brice, B. A. Cartwright, A. Doubleday, H. Higgs, T. Hummelink, G. G. Hummelink-Peters, O. Kennard, W. D. S. Motherwell, J. R. Rodgers and D. G. Watson, The Cambridge Crystallographic Data Centre: computer-based search, retrieval, analysis and display of information, Acta Crystallogr., Sect. B, 1979, 35, 2331 and references therein.

2 Inorganic Crystal Structure Data Base, Gmelin Institut, Fachinformationszentrum, Karlsruhe, Release 98/1.

3 C. R. Knowles, F. F. Rinaldi and J. V. Smith, Indian Mineral., 1956, 6, 127; F. Mazzi and E. Galli, Am. Minral., 1978, 63, 448; F. Pechar, Zeolites, 1988, 8, 247

4 C. Caranoni, G. Pepe and L. Capella, Acta Crystalllogr., Sect. B, $1978, \mathbf{3 4}, 741$

5 M. A. Marques and M. I. DeBarros Marques, Proc. K. Ned. Akad. Wet. Ser. B: Phys. Sci. 1974, 77, 286; W. Bol and T. Welzen, Chem. Phys. Lett., 1977, 49, 189; R. Caminiti, G. Licheri, G. Piccaluga, G. Pinna and T. Radnai, J. Chem. Phys., 1979, 71, 2473; R. Caminiti and T. Radnai, Z. Naturforsch., Teil A, 1980, 35, 1368

6 P. Lindqvist-Reis, A. Muñoz-Páez, S. Diaz-Moreno, S. Pattanaik, I. Persson and M. Sandström, Inorg. Chem., 1998, 37, 6675.

7 J. Blixt, J. Glaser, J. Mink, I. Persson, P. Persson and M. Sandström, J. Am. Chem. Soc., 1995, 117, 5089.

8 P. Lindqvist-Reis, S. Pattanaik, M. Sandström and I. Persson, unpublished results.

9 P. Lindqvist-Reis, Lamble, K. S. Pattanaik, M. Sandström and I. Persson, Phys. Chem., Sect. B, 2000, 104, 402.

10 J. Näslund, P. Lindqvist-Reis, M. Sandström and I. Persson, Inorg. Chem., 2000, 39, 4006.

11 R. D. Shannon, Acta Crystallogr., Sect. A, 1976, 32, 751.

12 D. T. Richens, The Chemistry of Aqua Ions, John Wiley and Sons, New York, 1997

13 J. K. Beattie, S. P. Best, B. W. Skelton and A. H. White, J. Chem. Soc., Dalton Trans., 1981, 2105; R. S. Armstrong, K. B. Beattie, S. P. Best, G. P. Braithwaite, P. Del Favero, B. W. Skelton and A. H. White, Aust. J. Chem., 1981, 43, 393.

14 K. Pannerselvan, M. Soriano-Garcia, S. Holguin-Quinones and E. M. Holt, Acta Crystallogr. Sect. C, 1996, 52, 1605. 
15 M. Calligaris and O. Carugo, Coord. Chem. Rev., 1996, 153,

16 M. J. Harrowfield, B. W. Skelton and A. H. White, Aust. J. Chem., 1990, 43, 759 .

17 G. Ma, A. Molla-Abbassi, M. Kritikos, A. Ilyukhin, F. Jalilehvand, V. Kessler, M. Skripkin, M. Sandström, J. Glaser, J. Näslund and I. Persson, Inorg. Chem., 2001, 40, 6432.

18 K. Starke, J. Inorg. Nucl. Chem., 1959, 11, 77.

19 J. Selbin, W. E. Bull and L. H. Holmes, J. Inorg. Nucl. Chem., 1961 , 16, 219

20 STOE Image Plate Diffractometer Software (IPDS), version 2.87, STOE \& Cie GmbH, Darmstadt, Germany, 1997.

21 (a) X-SHAPE version $1.02 ;(b)$ X-RED version 1.09 , STOE \& Cie GmbH, Darmstadt, Germany, 1997.

22 G. M. Sheldrick, Acta Crystallogr., Sect. A, 1990, 46, 467.

23 G. M. Sheldrick, SHELXL97, A Program for Crystal Structure Solution and Refinement, University of Göttingen: Germany, 1997; http://shelx.uni-ac.gwdg.de/SHELX/.

24 A. Thompson, D. Attwood, E. Gullikson, M. Howells, K.-J. Kim, J. Kirz, J. Kortright, I. Lindau, P. Pianatta, A. Robinson, J. Scofield, J. Underwood, G. Vaughan, Williams and H. Winick, X-ray Data Booklet, LBNL/PUB-490 Rev. 2, Lawrence Berkeley National Laboratory, Berkeley, CA 94720, 2001.

25 G. N. George and I. J. Pickering, EXAFSPAK: A Suite of Computer Programs for EXAFS Analysis, SSRL, Stanford University, CA, 1993.

26 The theory and procedure is described in: F. Jalilehvand, Structutre of Hydrated Ions and Cyano Complexs by X-Ray Absorption Spectroscopy, Doctoral Thesis, Royal Institute of Technology,
Stockholm, 2000; http://media.lib.kth.se:8080/dissengrefhit.asp?dissnr $=296$.

27 S. P. Cramer, K. O. Hodgson, E. I. Stiefel and W. E. Newton, J. Am. Chem. Soc., 1978, 100, 2748.

28 S. L. Zabinsky, J. J. Rehr, A. Ankudinov, R. C. Albers and M. J. Eller, J. Phys. Rev. B, 1995, 52, 2995.

29 J. Mink and L. M. Mink, Computer Program System for Vibrational Analyses of Polyatomic Molecules, Technical Report, Erlangenand Stockholm 1993;; available from Prof. J. Mink, Institute of Isotopes and Surface Chemistry, Chemical Research Center of the Hungarian Academy of Sciences, P. O. Box 77, H-1525 Budapest and Analytical Chemistry Department, University of Veszprém, P. O. 158, Hungary.

30 W. T. Robinson, C. J. Wilkins and Z. Zeying, J. Chem. Soc., Dalton Trans., 1990, 219.

31 P. Lindqvist-Reis, Structure of Solvated Metal Ions, Doctoral Thesis, Royal Institute of Technology (KTH), Stockholm, Sweden, 2000. Available at http://www.lib.kth.se/Sammanfattningar/ reis000614.pdf.

32 P. Lindqvist-Reis, J. Näslund, M. Sandström and I. Persson, J. Chem. Soc., Dalton Trans., 2000, 16, 2703.

33 T. G. Cherkasova, Zh. Neorg. Khim., 1994, 39, 1316.

34 E. I. Steifel and G. F. Brown, Inorg. Chem., 1972, 11, 434.

35 J. M. Hook, P. A. W. Dean and D. C. R. Hockless, Acta Crystallogr., Sect. C, 1995, 51, 1547.

36 A. Molla-Abbassi, M. Skripkin, J. Mink, I. Persson, M. Sandström and P. Lindqvist-Reis, Unpublished results.

37 M. Tranquille and M. T. Forel, Spectrochem. Acta, Part A, 1972, 28, 1305. 